\title{
CALCULATION OF GRAIN-BOUNDARY THICKNESS IN POLYGRYSTALLINE ICE OF LOW SALINITY
}

\author{
By Amiya K. Chatterjee and H. H. G. Jellinek \\ (Department of Chemistry, Clarkson College of Technology, Potsdam, New York I3676, \\ U.S.A.)
}

\begin{abstract}
Grain-boundary thickness in polycrystalline ice is a function of time (age), salinity, temperature, and mode of sample preparation. It is directly proportional to the salinity of the ice and the numberaverage grain diameter (spheres) or edge-length (cubes). Practically the total salt content resides in the grain boundary for low salinity ice samples. The grain-boundary thickness $\delta$ is also directly proportional to growth time of the grains raised to a power $n(n=0.25$ to 0.3$)$ and increases exponentially with absolute temperature for constant salinity and age. The energy of activation for growth increases with salinity. The results of the grain-boundary thickness calculations are useful for evaluating grain-boundary diffusion coefficients.
\end{abstract}

Resumé. Calcul de l'épaisseur de la couche limite des grains dans la glace polycristalline à faible salinité. L'épaisseur de la couche limite des grains dans la glace polycristalline est fonction du temps (age de la glace), de la salinité, de la température et du mode de préparation de l'échantillon. Elle est directement proportionnelle à la salinité de la glace et au nombre exprimant le diamètre moyen des grains (case des grains sphériques) ou la longueur du côté des grains (grains cubiques). Pratiquement, la totalité de la teneur en sel est concentrée dans la couche limite pour les échantillons de glace à faible salinité. L'épaisseur $\delta$ de la couche limite des grains est aussi directement proportionnelle au temps de croissance des grains élevé à une puissance $n(n=0,25$ à 0,3$)$ et croît exponentiellement avec la température absolue à salinité et âge constant. L'énergie d'activation nécessaire à la croissance des grains augmente avec la salinité. Les résultats des calculs d'épaisseur de la couche limite des grains sont utiles pour l'évaluation des coefficients de diffusion dans les couches limites.

Zusammenfassung. Berechung der Korngrenzendicke in polykristallinem Eis mit geringem Salzgehalt. Die Korngrenzendicke in polykristallinem Eis ist eine Funktion der Zeit (des Alters), des Salzgehaltes, der Temperatur und der Art der Probenpräparierung. Sie ist direkt proportional zum Salzgehalt des Eises und zum mittleren Korndurchmesser (bei Kugeln) oder zur mittleren Kantenlänge (bei Kuben). Praktisch konzentriert sich der gesamte Salzgehalt bei schwach salzigen Proben auf die Korngrenzen. Die Korngrenzendicke $\delta$ ist auch direkt proportional zur Wachstumszeit der Körner mit dem Exponenten $n(n=0,25$ bis 0,3$)$ und steigt exponentiell mit der absoluten Temperatur bei konstantem Salzgehalt und Alter an. Die Aktivationsenergie für das Wachstum steigt mit dem Salzgehalt. Die Ergebnisse der Berechnungen von Korngrenzendicken sind zur Ermittlung der Diffusionskoeffizienten der Korngrenzen nützlich.

GraIn growth of pure and saline polycrystalline ice has been studied recently by Jellinek and Gouda (1969). Also the effect of applied tensile stress on the rate of grain growth of pure polycrystalline ice has been investigated (Jellinek and Juznic, r 97o[b]). Diffusion of radioactive cesium and sodium, respectively, through polycrystalline ice was also studied (Jellinek and Chatterjee, I97I; Jellinek and Juznic, I970[a]). Two types of diffusion have to be considered for such ice, as is also the case with polycrystalline metals, i.e. volume or lattice diffusion and grain-boundary diffusion. In order to evaluate diffusion coefficients of the latter, the grain-boundary thickness has to be known; this can be calculated accurately for ice of low salinity with the help of the $\mathrm{H}_{2} \mathrm{O} / \mathrm{NaCl}$ phase diagram. Veynberg (I940, p. 500-05) made such calculations as early as i 940 . However, information concerning growth rates of number-average grain diameters as functions of salinity, time and temperature was not available then. Jellinek and Gouda ( 1969 ) have provided experimental data in this respect and it is now possible to calculate grain-boundary thicknesses based on experimental results. The salinity affects profoundly the mechanical and morphological properties of ice (Shumskiy, I 955; English translation p. 98 Pounder, I965). In polycrystalline ice of low salinity, practically all salt is contained in the grain boundary (see, e.g. De Micheli and Iribarne, I 969) which may be a liquid solution above, and a solid one below, the eutectic temperature. Sea ice contains numerous brine pockets and channels and hence does not contain all salt in the boundaries. 
The calculations presented here are in essence similar to those of Veynberg (I940, p. 500-05), but the approach is not the same; in addition, as pointed out above, actual grainboundary thickness, $\delta$, is calculated on the basis of measurements of grain diameter as function of salinity, age and temperature.

\section{Derivation OF FUNDAMENTAL EQUATION}

The grain boundary in saline polycrystalline ice is given by the amount of substance necessary to form an aqueous saline solution (or a solid one) containing all salt at the particular temperature in question in accordance with the $\mathrm{H}_{2} \mathrm{O} / \mathrm{NaCl}$ phase diagram. Let $s$ and $p$ be the salinities of the saline ice or saline melt solution and of the grain boundary, respectively; salinity is defined here as grams of salt per I 000 grams of saline melt solution or in $\%$ at the absolute temperature $T$. The number-average diameter of grains, considered as spheres, were experimentally determined for various conditions by thin-section analysis (Jellinek and Gouda, 1969).

If $x$ is the mass of water plus all salt in the sample needed to form the grain boundary from unit mass of ice of salinity $s$, then this boundary contains $p x / \mathrm{I}$ ooo, or $p x / \mathrm{I}$ ooo $=s / \mathrm{I}$ o0o of salt; the grain boundary contains all the salt in the sample. The volume of the grain boundary is $x / \rho_{\bar{b}}, T=s / p \rho_{\mathrm{gb}, T}$, where $\rho_{\mathrm{gb}, T}$ is the density of the grain boundary at $T_{\mathrm{abs}}$. The salinity of the liquid (or solid boundary solution) at this temperature is obtained from the $\mathrm{H}_{2} \mathrm{O} / \mathrm{NaCl}$ phase diagram. The latter was determined by Guthrie, Rodebush and Chretien. The data of these three authors agree fairly closely (Timmermans, ig6o, p. 309-10). The volume of the ice (all grains) at temperature $T$ is given by $(\mathrm{I}-x) / \rho_{\mathrm{i}, T}=(\mathrm{I}-s / p) / \rho_{\mathrm{i}, T}$, where $\rho_{\mathrm{i}, T}$ is the density of ice at temperature $T$.

If the volume* average edge-length of the grains, considered as cubes, is $\bar{b}$, then the volume of $\mathcal{N}$ grains is given by

$$
\mathcal{N} \bar{b}^{3}=(\mathbf{I}-s / p) / \rho_{\mathbf{i}, T}
$$

and the volume of the grain boundary is

$$
\mathcal{N}\left[(\bar{b}+\delta)^{3}-\bar{b}^{3}\right]=s / p \rho_{\mathrm{gb}, T} .
$$

Eliminating $\mathcal{N}$ from Equation (2) gives the grain-boundary thickness $\delta$,

$$
\delta=\bar{b}\left[\left(\frac{s \rho_{\mathrm{i}, T}}{(p-s) \rho_{\mathrm{gb}, T}}+\mathrm{I}\right)^{\frac{1}{3}}-\mathrm{I}\right] .
$$

For prisms with average quadratic cross-section $\bar{b}^{2}$, one obtains

$$
\delta \approx \bar{b}\left[\left(\frac{s \rho_{\mathrm{i}, T}}{(p-s) \rho_{\mathrm{gb}, T}}+\mathrm{I}\right)^{\frac{1}{2}}-\mathrm{I}\right]
$$

If $\delta \ll \bar{b}$ and $s \ll p$, which is the case here, then $(\bar{b}+\delta)^{3} \approx \bar{b}^{3}+3^{2} \delta$ and $(\bar{b}+\delta)^{2} \approx \bar{b}^{2}+2 \bar{b} \delta$ and $p-s \approx p$; hence Equations (3) and (4) simplify, respectively, to

and

$$
\delta=\frac{s \rho_{\mathrm{i}, T} \bar{b}}{3 p \rho_{\mathrm{gb}, T}}
$$

$$
\delta=\frac{s \rho_{\mathrm{i}, T} \bar{b}}{2 p \rho_{\mathrm{gb}, T}}
$$

The grain-boundary thickness is directly proportional to $s$ and $\bar{b}$, respectively. The case for spherical grains is somewhat more complicated as the grain boundary is not of uniform thickness. It is useful in this case to define a "theoretical" grain-boundary thickness $\delta / 2$ here

* $\bar{b}$ was erroneously designated as number- instead of as volume-average diameter in Jellinek and Gouda (1969), Jellinek and Juznic (1970[b]) and Jellinek and Chatterjee (1971). 
surrounding each ice sphere. The overall geometry is neglected, however the correct total ice-grain and grain-boundary volumes are taken. Each sphere of number-average diameter $\bar{b}$ is assumed to be enveloped by a grain boundary of thickness $\delta / 2$. The total ice-volume is again $(\mathrm{I}-s / p) / \rho_{\mathrm{i}, T}$ and the total grain-boundary volume is given by $s / p \rho_{\mathrm{gb}, T}$ as before. Hence Equations (I) and (2) contain a factor $\pi / 6$ on their left sides. The resulting equation is given by Equation (3), which simplifies for $\bar{b} \gg \delta$ to Equation (3a). $\delta$ in Equation (3a) is here twice the grain boundary thickness. Equation $(4 \mathrm{a})$ is valid for cylinders of diameter $\bar{b}$; here again $\delta$ is twice the thickness. The number-average grain diameters (including the grain boundary envelopes, which are too thin to be measured separately) were experimentally determined as function of time $t$ for overall salinities $s=0 \%$ and $s=\mathrm{r} \%$ by Jellinek and Gouda (1969). The general functional relationship of $\bar{b}$ and $t$ (growth law) is given by the expression

$$
\bar{b}=K_{\exp } t^{n}
$$

where $K_{\exp }$ is a rate constant and $n$ is also a constant. Hence for $s=\mathrm{I} \%$

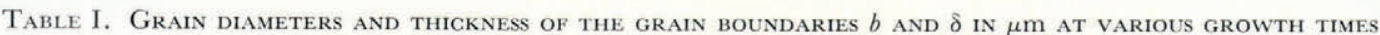
OF ICE OBTAINED FROM EQUATIONS $(3 \mathrm{a})$ AND $(4 \mathrm{a}), \delta(3)$ AND $\delta(4)$ RESPECTIVELY. IN THE CASE OF SPHERES $\delta$ REPRESENTS TWICE GRAIN-BOUNDARY THICKNES

\begin{tabular}{|c|c|c|c|c|c|c|c|c|c|c|}
\hline \multirow{4}{*}{$\begin{array}{c}\text { Temp. } \\
\text { C: }\end{array}$} & \multirow{4}{*}{$\underset{\%}{p}$} & \multirow{2}{*}{$\begin{array}{c}\rho_{\mathrm{i}} \\
\mathrm{Mg} / \mathrm{m}^{3}\end{array}$} & \multirow{2}{*}{$\begin{array}{c}\rho_{\mathrm{gb}} \\
\mathrm{Mg} / \mathrm{m}^{3}\end{array}$} & \multirow{2}{*}{$\begin{array}{c}s \\
\% \\
\% o\end{array}$} & \multicolumn{6}{|c|}{ Days } \\
\hline & & & & & 0.5 & 1 & 2 & 4 & 7 & 12 \\
\hline & & \multirow{10}{*}{0.9996} & \multirow{10}{*}{ I.0494 } & & $b=396$ & $49^{\circ}$ & 605 & $74^{8}$ & & 1008 \\
\hline & & & & 0.0586 & $\begin{array}{l}\delta(3)=0.115 \\
\delta(4)=0.173\end{array}$ & $\begin{array}{l}0.143 \\
0.214\end{array}$ & $\begin{array}{l}0.176 \\
0.264\end{array}$ & $\begin{array}{l}0.218 \\
0.326\end{array}$ & $\begin{array}{l}0.257 \\
0.385\end{array}$ & $\begin{array}{l}0.29 \\
0.44\end{array}$ \\
\hline \multirow{8}{*}{-3} & \multirow{8}{*}{64} & & & \multirow{3}{*}{0.1172} & $b=402$ & \multirow{3}{*}{$\begin{array}{l}495 \\
0.288 \\
0.43^{2}\end{array}$} & \multirow{3}{*}{$\begin{array}{l}609 \\
0.355 \\
0.531\end{array}$} & \multirow{3}{*}{$\begin{array}{l}75^{\circ} \\
0.437 \\
0.654\end{array}$} & 884 & \multirow{3}{*}{$\begin{array}{r}1013 \\
0.596 \\
0.884\end{array}$} \\
\hline & & & & & $\delta(3)=0.234$ & & & & o. $5^{15}$ & \\
\hline & & & & & $\delta(4)=3 \cdot 5^{\mathrm{I}}$ & & & & $0.77 \mathrm{I}$ & \\
\hline & & & & \multirow[b]{2}{*}{$0.293^{\circ}$} & $b=419$ & \multirow{2}{*}{$\begin{array}{l}509 \\
0.742 \\
1.1 \mathrm{I}\end{array}$} & \multirow{2}{*}{$\begin{array}{l}62 \mathrm{I} \\
\quad 0.906 \\
\mathrm{r} .35\end{array}$} & \multirow{2}{*}{$\begin{array}{l}75^{6} \\
\quad \text { I.1o } \\
\text { ז.65 }\end{array}$} & & \multirow{2}{*}{$\begin{array}{r}1026 \\
1.50 \\
2.24\end{array}$} \\
\hline & & & & & $\begin{array}{l}\delta(3)=0.661 \\
\delta(4)=0.913\end{array}$ & & & & $\begin{array}{l}1.29 \\
1.93\end{array}$ & \\
\hline & & & & \multirow{3}{*}{$0.585^{8}$} & $b=44^{6}$ & \multirow{3}{*}{$\begin{array}{r}534 \\
\quad 1.56 \\
2.32\end{array}$} & \multirow{3}{*}{$\begin{array}{l}640 \\
\quad 1.87 \\
2.79\end{array}$} & \multirow{3}{*}{$\begin{array}{r}767 \\
2.24 \\
3 \cdot 34\end{array}$} & & \multirow{3}{*}{$\begin{array}{r}1048 \\
3.06 \\
4.56\end{array}$} \\
\hline & & & & & $\delta(3)=\quad \mathrm{I} \cdot 30$ & & & & 2.59 & \\
\hline & & & & & $\delta(4)=\mathrm{I} .94$ & & & & & \\
\hline & & & & \multirow{3}{*}{0.0586} & $b=304$ & 360 & & 508 & $5^{8} 3$ & 668 \\
\hline & & & & & $\delta(3)=0.036$ & 0.043 & 0.051 & 0.061 & 0.070 & \\
\hline & & & & & $\delta(4)=0.055$ & 0.06 & 0.077 & 0.091 & 0.105 & \\
\hline & & & & 0.1172 & $\begin{aligned} b & =306\end{aligned}$ & 362 & & & & \\
\hline-10 & 146 & 0.9981 & I. I I 74 & & $\begin{array}{ll}\delta(3)= & 0.073 \\
\delta(4)= & 0.110\end{array}$ & $\begin{array}{l}0.087 \\
0.130\end{array}$ & $\begin{array}{l}0.103 \\
0.155\end{array}$ & $\begin{array}{l}0.122 \\
0.183\end{array}$ & $\begin{array}{l}0.14^{\circ} \\
0.210\end{array}$ & $\begin{array}{l}0.160 \\
0.240\end{array}$ \\
\hline & & & & 0.2930 & $b=3^{12}$ & 368 & 436 & $5^{15}$ & 589 & 672 \\
\hline & & & & & $\begin{array}{l}\delta(3)=0.187 \\
\delta(4)=0.280\end{array}$ & $\begin{array}{l}0.220 \\
0.330\end{array}$ & $\begin{array}{l}0.26 \mathrm{I} \\
0.39 \mathrm{I}\end{array}$ & $\begin{array}{l}0.308 \\
0.462\end{array}$ & $\begin{array}{l}0.35^{2} \\
0.528\end{array}$ & $\begin{array}{l}0.40 \\
0.60\end{array}$ \\
\hline & & & & 0.5858 & $b=324$ & 379 & 446 & & 596 & 679 \\
\hline & & & & & $\delta(3)=0.3^{88}$ & 0.454 & 0.534 & o.628 & 0.714 & \\
\hline & & & & & $\delta(4)=0.580$ & 0.680 & 0.800 & $0.93^{8}$ & I.07 & \\
\hline & & & & & $b=15^{\circ}$ & I93 & & & $37^{8}$ & \\
\hline & & & & 0.0586 & $\delta(3)=0.01$ & o.o & 0.017 & o.o & 0.026 & 0.03 \\
\hline & & & & & $\begin{aligned} 0(4) & =0.015 \\
b & =\end{aligned}$ & & 0.0 & 0.0 & & \\
\hline & & & & & $\delta(3)=0.020$ & 0.026 & $\begin{array}{l}239 \\
0.033\end{array}$ & $\begin{array}{l}304 \\
0.042\end{array}$ & $\begin{array}{ll}309 \\
0.0\end{array}$ & $\begin{array}{r}444 \\
0.06\end{array}$ \\
\hline-23 & 236 & $0.993^{\circ}$ & I.1970 & & $\delta(4)=0.031$ & 0.039 & 0.049 & 0.063 & 0.076 & \\
\hline & & & & & $b=143$ & & & 286 & 345 & \\
\hline & & & & $0.293^{\circ}$ & $\begin{array}{ll}\delta(3)= & 0.049 \\
\delta(4)= & 0.074\end{array}$ & $\begin{array}{l}0.062 \\
0.093\end{array}$ & $\begin{array}{l}0.078 \\
0.117\end{array}$ & $\begin{array}{l}0.098 \\
0.147\end{array}$ & $\begin{array}{l}0.119 \\
0.178\end{array}$ & $\begin{array}{l}0.14^{2} \\
0.213\end{array}$ \\
\hline & & & & & & 167 & 206 & & & 360 \\
\hline & & & & $0.5^{8} 5^{8}$ & $\begin{array}{ll}\delta(3)= & 0.092 \\
\delta(4)= & 0.138\end{array}$ & $\begin{array}{l}0.115 \\
0.172\end{array}$ & $\begin{array}{l}0.142 \\
0.212\end{array}$ & $\begin{array}{l}0.175 \\
0.262\end{array}$ & 0.210 & $0.24^{8}$ \\
\hline & & & & & & & & & 0.314 & \\
\hline
\end{tabular}




$$
\delta=\frac{s \rho_{\mathrm{i}, T}}{3 p \rho_{\mathrm{gb}, T}} K_{\mathrm{exp}} t^{n} .
$$

Equation (6) shows that $\delta$, or $\delta / 2$, increases directly proportional to the $n$th power of time, and to $s$, respectively.

The temperature dependence of $K_{\exp }$ for the growth of grains in the range from $-3{ }^{\circ} \mathrm{C}$ to $-30^{\circ} \mathrm{C}$ obeyed an Arrhenius equation. Hence,

$$
\delta=\frac{s \rho_{\mathrm{i}, T} t^{n}}{3 p \rho_{\mathrm{gb}, T}} A \exp (-E / R T)
$$

and $\log \delta$ decreases linearly as reciprocal absolute temperature increases for any one time and salinity.

Average values of $n$ for $s=0 \%$ and $s=1 \%$ are 0.30 and 0.25 respectively (Jellinek and Gouda, I969), the $K_{\exp }$ values range from $4.85 \times 10^{-2}\left(\mu \mathrm{m} \mathrm{day}^{-n}\right)$ at $-3.0^{\circ} \mathrm{C}$ to I.I $2 \times \mathrm{IO}^{-2}\left(\mu \mathrm{m} \mathrm{day}^{-n}\right)$ at $-36^{\circ} \mathrm{C}$ for $s=0 \%$, and from 5.69 to $0.94\left(\mu \mathrm{m} \mathrm{day}{ }^{-n}\right)$ for the same temperature when $s=1.0 \%$.

A direct linear relationship was assumed between $\bar{b}$ and $s$ at any one constant time $t$ and temperature $T$. Hence $\bar{b}$ can be expressed by

$$
\bar{b}=K_{t, T^{s}, T}+m_{t, T}=K_{\exp } t^{n}+\bar{b}_{0} .
$$

$\bar{b}_{0}$ is the average diameter at $t=0$, which often can be neglected. $K_{\exp }$ and $n$ were derived as function of salinity for constant times $t$ from plots of $\log \bar{b}$ versus $\log t$ for various salinities. Almost linear relationships were obtained for either parameter. $\delta$ values for spheres, cubes, cylinders, and prisms were calculated from experimental values for $\bar{b}$ found previously

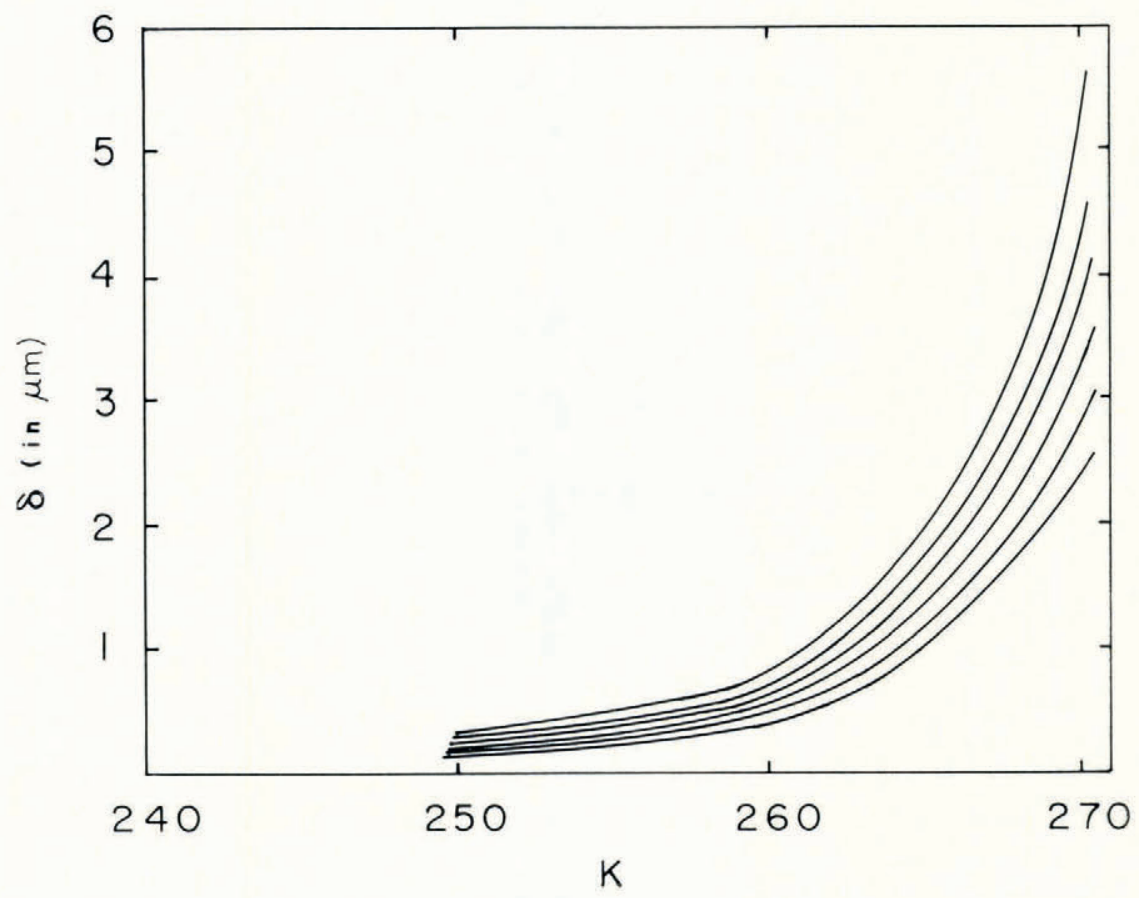

Fig. I. $\delta$ (spheres) versus $T_{\text {abs }}$ for various growth times $(s=I \%), t=0.5, I, 2,4,7, I 2$ days. The points in each curve are in the same sequence as the $t$ values above, starting from the left. ( $\delta$ here is twice the boundary thickness.) 
(Jellinek and Gouda, I969) and are contained in Table I ( $\delta$ values for spheres represent here twice the boundary thickness). Figure I shows plots of $\delta$ (spheres) versus absolute temperature for different growth times, obtained from Equation (7). $\left(s=\mathrm{I} \%, A=3.5^{8} \times \mathrm{Io}^{8} \mu \mathrm{m}\right.$; $E=7.2 \mathrm{kcal} / \mathrm{mol})$.

\section{Discussion}

It is interesting to note (see Table I) that at temperatures above the eutectic point the grain diameter $\bar{b}$ increases, while at temperatures below it, $\bar{b}$ decreases with salinity. It was remarked in the previous paper (Jellinek and Gouda, I969) that growth in saline ice is slower near or below the eutectic temperature than that in pure $(s=0)$ ice, while the reverse is true at higher temperatures. This is probably due to the fact that the grain boundary is quasi-liquid above and quasi-solid below the eutectic temperature.

In sea ice $(c .5 \%)$ or ice of relatively high salinity, there usually exist brine pockets or channels in the grains, especially if rapid freezing has taken place. Hence the calculations presented here will not be accurate enough for such cases. These pockets give an opaque appearance to ice.

Grain thickness obtained on the basis of calculations presented here have been used for evaluating grain-boundary diffusion coefficients for saline polycrystalline ice (Jellinek and Chatterjee, 1971).

Veynberg's calculations are speculative, as some arbitrary values have been taken for grain diameters. Also data were not available on the effect of temperature at that time, and he assumed an approximate coefficient of thermal linear expansion for ice grains in order to compute diameters at different temperatures, which lead to erroneous results. He also was not aware that grain diameter and grain-boundary thickness are functions of the age of ice samples.

\section{Acknowledgement}

This work was made possible by a Grant from the U.S. Department of the Interior, Office of Saline Water, No. I4-OI-OooI-I 22.

MS. received I8 August 1970 and in revised form 13 January 1971

\section{REFERENCES}

De Micheli, S. M. de, and Iribarne, J. V. i963. La solubilité des electrolytes dans la glace. Journal de Chimie physique et de Physico-chimie biologique, Tom. 6o, No. 6, p. 767-74.

Jellinek, H. H. G., and Chatterjee, A. K. I971. Diffusion of radioactive sodium in polycrystalline ice. Physica Status Solidi A, Vol. 4, No. 3, p. 173-79.

Jellinek, H. H. G., and Gouda, V. K. 1969. Grain growth in polycrystalline ice. Physica Status Solidi, Vol. 3 I, No. I, p. $4^{1} 3^{-2} 3$.

Jellinek, H. H. G., and Juznic, K. 1970[a]. Diffusion of radioactive cesium in polycrystalline ice. Physica Status Solidi A, Vol. 2, No. 4, p. $837-46$.

Jellinek, H. H. G., and Juznic, K., I970[b]. Grain growth of polycrystalline ice under stress. (In Onogi, S., ed. Proceedings of the fifth International Congress of Rheology, 1968. Tokyo, University of Tokyo Press, Vol. 2, p. 407I9.)

Pounder, E. R. 1965. The physics of ice. Oxford, Pergamon Press. (The Commonwealth and International Library. Geophysics Division.)

Shumskiy, P. A. I955. Osnovy strukturnogo ledovedeniya. Petrografiya presnogo l'da kak metod glyatsiologicheskogo issledovaniya. Moscow, Izdatel'stvo Akademii Nauk SSSR. [English translation: Principles of structural glaciology: the petrography of fresh-water ice as a method of glaciological investigation. Translated from the Russian by David Kraus. New York, Dover Publications, 1964.]

Timmermans, J. 1960. The physico-chemical constants of binary systems in concentrated solutions. Vol. 3. New York, Interscience Publishers Inc. p. 309-16.

Veynberg, B. P. I940. Led: svoystva, vozniknoveniye $i$ ischeznoveniye l'da [Ice, its properties, appearance and disappearance]. Moscow, Gosudarstvennoye Izdatel'stvo Tekhniko-Teoreticheskoy Literatury. 